ISSN 1392-3196 / e-ISSN 2335-8947

Zemdirbyste-Agriculture, vol. 103, No. 1 (2016), p. 11-20

DOI 10.13080/z-a.2016.103.002

\title{
Winter oilseed rape and weed competition in organic farming using non-chemical weed control
}

\author{
Rimantas VELIČKA ${ }^{1,2}$, Aušra MARCINKEVIČIENË $\dot{1}^{1,2}$, Rita PUPALIENË $^{1,2}$, \\ Lina Marija BUTKEVIČIENE $\dot{E}^{1,2}$, Robertas KOSTECKAS ${ }^{2}$, Sigitas ČEKANAUSKAS ${ }^{2}$, \\ Zita KRIAUČIŪNIENÉ ${ }^{2}$ \\ ${ }^{1}$ Institute of Agroecosystems and Soil Science, Aleksandras Stulginskis University \\ Studentų 11, Akademija, Kaunas distr., Lithuania \\ ${ }^{2}$ Experimental Station, Aleksandras Stulginskis University \\ Rapsų 7, Noreikiškès, Kaunas distr., Lithuania \\ E-mail: zita.kriauciuniene@asu.lt
}

\begin{abstract}
One of the reasons why the area sown with oilseed rape in organic farms is not expanding is problems with weed, disease, and pest control as well as low seed yield. There is a lack of investigations on oilseed rape cultivated in an organic system, especially employing innovative weed control methods. To fill this gap in knowledge, field experiments were conducted at the Experimental Station of Aleksandras Stulginskis University in 2012-2013 with the aim of identifying and assessing the impact of different non-chemical weed control methods (thermal - TWC, mechanical - MWC and smothering - SMT) on weed competitiveness in winter oilseed rape (Brassica napus L.) crops during the autumn vegetation period in an organic farming system with and without the use of plant bio-activators in a soil with a regular $(23-25 \mathrm{~cm})\left(1^{\text {st }}\right.$ experiment $)$ and with a thickened $(48-50 \mathrm{~cm})\left(2^{\text {nd }}\right.$ experiment) humus layer. It was found, that compared with thermal and mechanical weed control, in the treatment using smothering weed control and spraying with plant bio-activators or not spraying, the density of winter rape crop in the soil with a regular humus layer was significantly $(P \leq 0.05)$ lower $(1.2$ to 5.3 times $)$; in the soil with a thickened humus layer, the density of winter rape crop was 1.5 to 5.9 times lower. In winter oilseed rape during autumn vegetation period, 20-22 weed species were found, including 18-19 annuals. Stellaria media (L.) Vill., Veronica arvensis L., Sinapis arvensis L. and Capsella bursa-pastoris (L.) Medik. were the predominant weeds. In the soil with a regular and a thickened humus layer, thermal and mechanical weed control significantly $(P \leq$ 0.05 ) decreased the number of weed seedlings (1.1 to 1.9 times) when plant bio-activators were used compared with the smothering treatment. Weed control in the smothering treatment in the soil with a regular and thickened humus layers was not effective. Mechanical weed control was more efficient than thermal. Application of plant bio-activators increased the efficiency of the thermal weed control.
\end{abstract}

Key words: Brassica napus, crop smothering ability, mechanical weed control, plant bio-activators, thermal weed control, weed species.

\section{Introduction}

At the beginning of the 1980 s, ideas about organic farming began to spread worldwide. The development of organic farming has been driven by growing concerns about protecting the environment, the efficient use of material and energy resources, and human health. There is an increasing need for healthy food that is not contaminated with pesticide residues; therefore, it is necessary to develop and improve organic farming systems for the production of different crops including oilseed rape, which is used for edible oil production. Organic oilseed rape farms are not expanding due to the problems with weeds, diseases, inadequate pest control and low seed yield. Weeds are natural components of plant communities in cultivated land (Mohammaddouste-Chamanabad et al., 2006). The species composition and abundance of weeds in crops are influenced by the

characteristics of the soil, crop competitive ability and soil cultivation practices. In particular, weed control measures have a greater influence than soil tillage on controlling the spread of weeds, especially perennials (Chamanabad, Asghari, 2009). The competitive ability of different agricultural crops is variable and depends on the biological properties of the plants, tillage, fertilization, seed rate and sowing time (Bečka et al., 2004; Bullied et al., 2006). By exploiting the competitive ability of a crop, the cost of weed control can be significantly reduced (Maikšteniene et al., 2009). Oilseed rape has a lower weed competitive ability than barley and winter wheat due to its long rosette development period (Velička, 2002).

The most efficient method of crop protection is integrated weed management, which combines a variety of weed control methods, including mechanical and thermal 
weed control, exploitation of crop competitive ability and other practices. Inter-row mechanical weed control is practiced in organic farms and can significantly reduce crop weediness. However, mechanical weed control in oilseed rape cultivation is limited. In addition, harrowing in an oilseed rape crop is not advisable due to possible plant damage. Thermal weed control is a newly developed method for controlling weeds in different crops. This method is based on heat spread regularities and involves the use of thermo-engineering techniques and equipment. In thermal weed control, a heat source that creates a high temperature environment around the plant is used (Sirvydas, Kerpauskas, 2012). Several methods, such as flame (Ascard, 1998; Ulloa et al., 2012; Datta, Knezevic, 2013), hot water (Hansson, Ascard, 2002; Quarles, 2004), hot foam (Kempenaar, Spijker, 2004), and water steam, have been used in thermal weed control (Kerpauskas et al., 2006; Virbickaitè et al., 2006; Staniulienè, 2010; Sirvydas, Kerpauskas, 2012). Special conditions are created in the plant environment when using the steam method. The working environmental temperature is $100^{\circ} \mathrm{C}$, and the heat transfer process is intense, with steam condensation occurring on the plant and soil surfaces (Sirvydas, Kerpauskas, 2012). Virbickaitè et al. (2006) found that the efficiency of thermal weed control using steam for annual weeds was $22.5 \%$ higher than that of mechanical weed control; however, the efficacy of mechanical weed control for perennial weeds was $32.0 \%$ higher than that of the thermal method. Kerpauskas et al. (2006) reported that thermal weed control using steam lowered weed biomass by $44.0 \%$ and increased barley grain yield by $22.0 \%$. Thermal weed control using steam is most effective when the soil is undisturbed and weed seed germination is not activated (Sirvydas, Kerpauskas, 2012). Staniuliene (2010) reported that weeds belonging to the Poaceae family are the most sensitive to high temperatures at the 1-2 leaf stage. In later stages, a prolonged high temperature exposure is required.

As the use of organic fertilizers and plant bioactivators increases, it is critical to investigate their effectiveness on organic crops. Research conducted in Lithuania showed that liquid organic fertilizers and growth promoters have a positive impact on winter cereals, but their effectiveness is variable (Sliesaravičius et al., 2006). The use of liquid organic fertilizers and growth promoters has a significant influence on grain yield and crop biometrical indices (Jablonskytè-Rašče et al., 2012). Pekarskas et al. (2013) found that the weediness of winter wheat and winter rye crops treated with liquid bioorganic fertilizers and growth promoters was significantly lower compared with untreated crops. Different bioorganic fertilizers and growth promoters often have different impacts on crops; however, there is a lack of such studies for oilseed rape crops.

In other countries, there have been several investigations on oilseed rape cultivated in an organic farming system (Valantin-Morison et al., 2007; Veromann et al., 2009; Engström et al., 2014), but there is a lack of such studies for Lithuanian climatic conditions, especially with current and innovative weed control methods. This study aims to identify and assess the impact of different weed control methods and the use of plant bio-activators on winter oilseed rape and weed competitiveness in organic farming during an autumn vegetation period. We hypothesized that non-chemical weed control in combination with bio-activators can increase winter rape smothering ability of weeds in early stage of their growth and development. Further studies should focus on evaluating the influence of meteorological conditions on the efficiency of different weed control methods.

\section{Materials and methods}

Field experiments were performed in 20122013 at the Experimental Station of Aleksandras Stulginskis University $\left(54^{\circ} 53^{\prime} \mathrm{N}, 23^{\circ} 50^{\prime} \mathrm{E}\right)$. This study investigated the influence of different non-chemical weed control methods on winter rape (Brassica napus $\mathrm{L}$. ssp. oleifera biennis Metzg.) and weed competitiveness in organic farming with and without the use of plant bioactivators. Winter oilseed rape was cultivated in a soil with a regular humus layer $(23-25 \mathrm{~cm})\left(1^{\text {st }}\right.$ experiment) and in a soil with a thickened humus layer $(45-50 \mathrm{~cm})$ ( $2^{\text {nd }}$ experiment). The soils at the experimental site were classified as Calc(ar)i-Endohypogleyic Luvisol (Drainic) according to the IUSS Working Group WRB (2014). The soil agrochemical properties (mean data for 2012 and 2013) for $1^{\text {st }}$ experiment were as follows: $\mathrm{pH} 7.10$, humus $1.85 \%$, mobile $\mathrm{P}_{2} \mathrm{O}_{5} 234 \mathrm{mg} \mathrm{kg}^{-1}$ and mobile $\mathrm{K}_{2} \mathrm{O}$ $106 \mathrm{mg} \mathrm{kg}^{-1}$. For $2^{\text {nd }}$ experiment, the soil properties were: pH 7.10, humus $2.23 \%$, mobile $\mathrm{P}_{2} \mathrm{O}_{5} 191 \mathrm{mg} \mathrm{kg}^{-1}$ and mobile $\mathrm{K}_{2} \mathrm{O} 94.2 \mathrm{mg} \mathrm{kg}^{-1}$.

Treatments. A randomized split-plot design was used. The main plot treatments involved plant bio-activators as follows: 1) without application and 2) with application. The subplot treatments included a combination of non-chemical weed control measures, including the following treatments: 1) thermal (water steam) - TWC, 2) mechanical (inter-row loosening) MWC and 3) smothering (self-regulation) - SMT. Four replications were performed in this experiment. The size of the plot was $60 \mathrm{~m}^{2}(10 \times 6 \mathrm{~m})$, and the observation plot was $20 \mathrm{~m}^{2}(10 \times 2 \mathrm{~m})$.

The winter oilseed rape variety 'Sunday' (3 $\mathrm{kg} \mathrm{ha}^{-1}$ ) was cultivated. In 2012 it was sown on the $20^{\text {th }}$ of August and in 2013 on the $17^{\text {th }}$ of August with a seeder Multidrill M-300 ("Rabewerk", Germany). TWC and MWC were applied in the winter oilseed rape crop cultivated at a wide row spacing of $48 \mathrm{~cm}$ (Fig. $1 \mathrm{~A}$ ). A mobile thermal water steam device was used for TWC (thermal capacity $90 \mathrm{~kW}$, performance $120 \mathrm{~kg} \mathrm{~h}^{-1}$, with steam-fired liquefied gas). The steam temperature was $99^{\circ} \mathrm{C}$, and the heat exposure duration was $2 \mathrm{~s}$. For MWC, inter-rows were loosened twice using a soil loosener KOR-4.2-01 (Ukraine) at the BBCH 13-14 stage of the oilseed rape. In the bio-activator treatment, rape seed was treated before sowing using a bioorganic fertilizer (fulvic and humic acids $-9.09 \mathrm{~g} \mathrm{~L}^{-1}, \mathrm{~N}-0.35 \mathrm{~g} \mathrm{~L}^{-1}$, $\mathrm{P}-0.73 \mathrm{~g} \mathrm{~L}^{-1}, \mathrm{~K}-2.49 \mathrm{~g} \mathrm{~L}^{-1}, \mathrm{Mg}-283.8 \mathrm{mg} \mathrm{L}^{-1}, \mathrm{~B}-$ 
$0.36 \mathrm{mg} \mathrm{L}^{-1}, \mathrm{Cu}-0.90 \mathrm{mg} \mathrm{L}{ }^{-1}, \mathrm{Fe}-110.5 \mathrm{mg} \mathrm{L}{ }^{-1}, \mathrm{Mn}$ - $435.7 \mathrm{mg} \mathrm{L}^{-1}, \mathrm{Mo}-713.1 \mathrm{mg} \mathrm{L} \mathrm{L}^{-1}, \mathrm{Zn}-345.5 \mathrm{mg} \mathrm{L}^{-1}$, $\mathrm{Co}-51.95 \mathrm{mg} \mathrm{L}^{-1}, \mathrm{Se}-0.138 \mathrm{mg} \mathrm{L}^{-1}, \mathrm{Cd}-0.231 \mathrm{mg} \mathrm{L}^{-1}$, $\mathrm{Cr}-0.02 \mathrm{mg} \mathrm{L}^{-1},-\mathrm{Ni} 1.30 \mathrm{mg} \mathrm{L}^{-1}$, organic material $\left.9.09 \mathrm{~g} \mathrm{~L}^{-1}, \mathrm{C}_{\text {org }}-4.60 \mathrm{~g} \mathrm{~L}^{-1}\right)$. We used 0.51 of bioorganic fertilizer +101 of water per ton of seed. During vegetative growth, the crop was sprayed with $0.3 \%$ plant bioactivators containing 40\% neem (Azadirachta indica) seed oil soap and $40 \%$ organic material (only in 2012) and 50\% bitter quassia (Quassia amara) extract, 50\% natural origin oleic acid potassium soap and $85 \%$ organic material. In the SMT treatment, winter oilseed rape was cultivated at an inter-row spacing of $12 \mathrm{~cm}$ (Fig. $1 \mathrm{~B}$ ), and the TWC and MWC methods were not used. The winter oilseed rape crop replaced bare fallow (mouldboard plough) in an organic farming system.

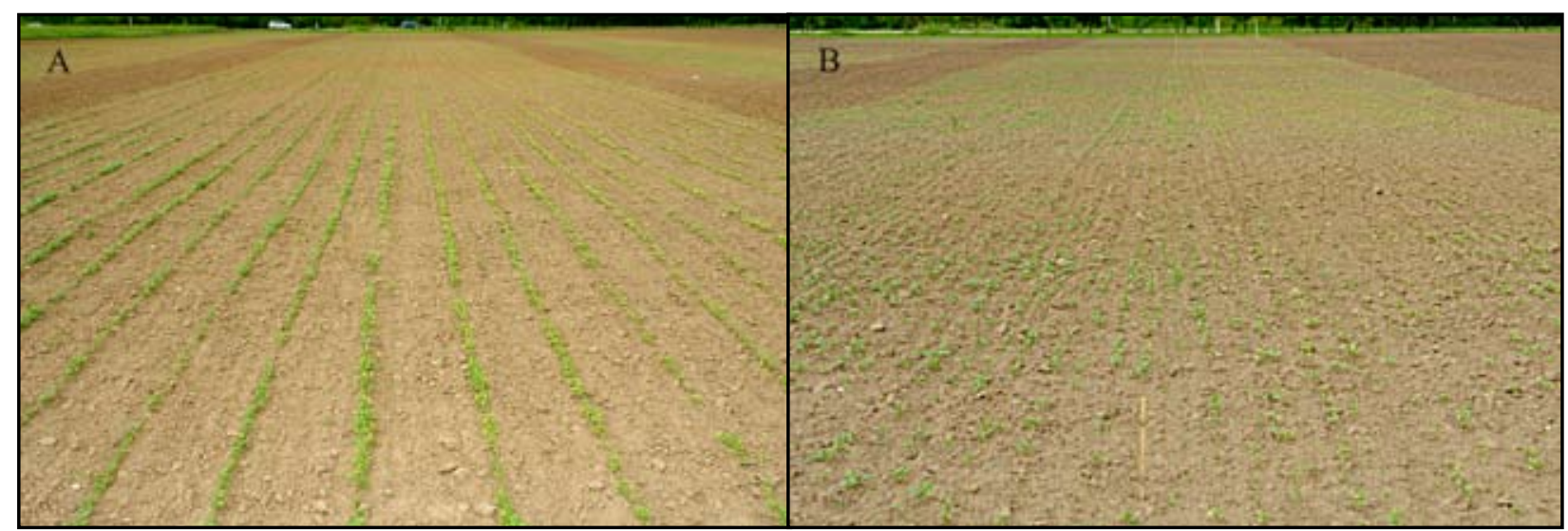

Figure 1. Thermal (TWC) and mechanical (MWC) weed control were applied in winter oilseed rape cultivated at a wide row spacing of $48 \mathrm{~cm}$ (A) and smothering (SMT) at an inter-row spacing of $12 \mathrm{~cm}$ (B)

Sampling procedures. The agrochemical characteristics of the soil were measured prior to the experiments in all replications. Composite soil samples from the $0-25 \mathrm{~cm}$ soil layer were collected using a Nekrasov auger (Russia). Soil pH was determined potentiometrically in $1 \mathrm{~N} \mathrm{KCl} \mathrm{extract.} \mathrm{Mobile} \mathrm{phosphorus}$ $\left(\mathrm{P}_{2} \mathrm{O}_{5}\right)$ and mobile potassium $\left(\mathrm{K}_{2} \mathrm{O}\right)\left(\mathrm{mg} \mathrm{kg}^{-1}\right.$ soil $)$ were determined using the Egner-Riehm-Domingo (A-L) method, and the humus content (\%) was determined using the Tiurin method.

In September the density (plants $\mathrm{m}^{-2}$ ) of the winter oilseed rape crop was estimated in each plot at four locations in $0.25 \mathrm{~m}^{2}$ plots.

The initial weed seedling abundance was determined prior to the application of TWC and MWC at the $\mathrm{BBCH} 13-14$ stage of the oilseed rape $\left(13^{\text {th }}-14^{\text {th }}\right.$ September). The number of weed seedlings was estimated in each replication in four randomly selected $0.10 \mathrm{~m}^{2}$ plots. The second set of observations was performed in defined weed counting plots seven days after the application of weed control $\left(25^{\text {th }}-26^{\text {th }}\right.$ September). The efficiency (E) of the different weed control methods with respect to the change in weed seedling number was calculated according to the following formula: $\mathrm{E}=\left(\mathrm{S}_{1}-\mathrm{S}_{2}\right) / \mathrm{S}_{1} \times 100 \%$, where $\mathrm{S}_{1}$ is the weed seedling number in $1 \mathrm{~m}^{2}$ before the weed control method was applied, $\mathrm{S}_{2}$ - the weed seedling number in $1 \mathrm{~m}^{2}$ after the application of weed control.

Meteorological conditions. Lithuania is located in a moderately cool climate zone with moderately hot summers and moderately cold winters. The average temperature in July is approximately $17^{\circ} \mathrm{C}$, and the average temperature in the winter is approximately $-5^{\circ} \mathrm{C}$. The highest amounts of precipitation usually occur during the summer and account for approximately 50\% of the annual precipitation.
The meteorological data during the experiment was obtained from the Kaunas Meteorological Station. The distance between the Meteorological Station and the area where the experiments were conducted is approximately $500 \mathrm{~m}$.

In 2012, the winter oilseed rape was sown on the $20^{\text {th }}$ of August. This month was not favourable for winter oilseed rape germination due to the lack of rainfall. There was sparse rain $(18.9 \mathrm{~mm})$ during the last ten days of this month, but the monthly hydrothermal coefficient (HTC) was 1.3 (optimal irrigation). September was favourable not only for winter oilseed rape but also for weed growth. The monthly average temperature was $1.1^{\circ} \mathrm{C}$ higher and precipitation was $14.4 \mathrm{~mm}$ higher compared with the longterm averages. The HTC measured in September was 1.7 (excess irrigation). October was warm (especially the first ten days) and humid. The rainfall in October exceeded the long-term average by $25.4 \mathrm{~mm}$. The average temperature in November was $3.3^{\circ} \mathrm{C}$ higher and rainfall was $22.6 \mathrm{~mm}$ higher than the long-term averages.

In 2013, the winter oilseed rape was sown on the $17^{\text {th }}$ of August. The monthly average temperature in August was $1.3^{\circ} \mathrm{C}$ above the long-term average, and precipitation was $13.1 \mathrm{~mm}$ higher. The HTC for August was 1.2 (optimal irrigation). The average temperature in September was close to the long-term mean, although the amount of precipitation was 2.0 times higher. The HTC for September was 3.1 (excess irrigation). The amount of rainfall in October was close to the long-term average, but the average temperature was $1.9^{\circ} \mathrm{C}$ higher. The HTC for October was 1.0 (optimal irrigation). The average temperature in November exceeded the long-term mean by $3.5^{\circ} \mathrm{C}$, and rainfall was $17 \mathrm{~mm}$ higher. 
Statistical analyses. The data from these experiments were statistically evaluated for quantitative characteristics using a spilt plot analysis. The analyses were performed using the statistical computer program SPLIT PLOT (Tarakanovas, 2002). If the weediness test data were not normally distributed, they were transformed using the function $y=\ln x$ prior to statistical evaluation.

\section{Results and discussion}

Main weeds species composition in winter oilseed rape during autumn vegetation. In 2012, during the autumn vegetation period of winter oilseed rape cultivated in the soil with a regular humus layer $\left(1^{\text {st }}\right.$ experiment) before the use of any weed control methods, 20 weed species were found, including 19 annuals and one perennial (Elytrigia repens (L.) Nevski). The weeds that were found belonged to 12 families (Boraginaceae, Asteraceae, Chenopodiaceae, Brassicaceae, Scrophulariaceae, Caryophyllaceae, Euphorbiaceae, Poaceae, Violaceae, Lamiaceae, Polygonaceae and Fumariaceae). The most abundant annual weed was Stellaria media (L.) Vill. (11.9-17.5 seedlings $\mathrm{m}^{-2}$ ) (Table 1).

More favourable conditions for the growth of these weeds' seedlings occurred in the oilseed rape cultivated with MWC and TWC and without the application of plant bio-activators. There was a low winter oilseed rape crop density in the SMT treatment and a high weed density. Annual weeds - Capsella bursa-pastoris (L.) Medik., Veronica arvensis L., Tripleurospermum perforatum (Mérat.) M. Laínz and Lamium amplexicaule L. - were particularly abundant, especially in the plots with the use of plant bio-activators. According to Arlauskienė and Maikštėnienè (2004), in lower density crops, annual weeds are more abundant than perennial weeds. Higher crop density increases the spread of perennial weeds, but the spread of annual weeds decreases up to $17 \%$ (Maikštėnienè et al., 2009).

In the 2013 autumn vegetation period of winter oilseed rape in the soil with a regular humus layer $\left(1^{\text {st }}\right.$ experiment), 21 weed species were found, including 18 annuals and 3 perennials. The weeds that were found belonged to 14 families (the same as in 2012 with the addition of Equisetaceae and Rubiaceae). The most abundant weed species were Veronica arvensis (28.8-58.1 seedlings $\mathrm{m}^{-2}$ ) and C. bursa-pastoris (7.5-17.5 seedlings $\mathrm{m}^{-2}$ ), especially in winter oilseed rape TWC and MWC plots (Table 1).

During the vegetation period in autumn 2012 prior to the use of weed control methods in the winter oilseed rape crop cultivated in the soil with a thickened humus layer ( $2^{\text {nd }}$ experiment), 21 weed species were found, including 18 annuals and three perennials. The weeds belonged to 12 families (Boraginaceae, Asteraceae, Chenopodiaceae, Brassicaceae, Scrophulariaceae, Caryophyllaceae, Euphorbiaceae, Poaceae, Violaceae, Lamiaceae, Polygonaceae and Fumariaceae). The most abundant of these were Stellaria media (12.5-26.3 seedlings $\mathrm{m}^{-2}$ ) and Sinapis arvensis (9.4-32.5 seedlings $\mathrm{m}^{-2}$ ), especially when plant bio-activators were not used. In the SMT plots, C. bursa pastoris, Viola arvensis and Veronica arvensis were the most abundant.
During the vegetation period of winter oilseed rape cultivated in the soil with a thickened humus layer $\left(2^{\text {nd }}\right.$ experiment) in the autumn of 2013 prior to the use of weed control, 22 weed species were found, including 18 annuals and four perennials. These weeds belonged to 12 families, which were the same as those identified in 2012, except that Fumariaceae was absent and Rubiaceae was present. The most abundant weeds were $S$. media, Viola arvensis and C. bursa-pastoris, especially in the SMT plots.

Pupaliene (2004) found that in the soil with a thickened humus layer, the number of perennial weeds and the dry matter content were lower. Additionally, this study established that the thickness of the humus layer affects the composition of weed species. In our experiment, when evaluating the influence of different weed control methods on the competitiveness of winter rape and weeds during the autumn vegetation period in the soil with a thickened humus layer, the number of perennial weed species was higher (3-4) compared with the experiments in the soils with a regular humus layer (1-3).

The competitiveness of winter oilseed rape and weeds. In 2012 and 2013, the lowest winter oilseed rape crop density in the soil with a regular humus layer $\left(1^{\text {st }}\right.$ experiment) occurred in the SMT treatment (Table 2). Crop density is particularly important for weed control in the early stages of rape growth (Morrison et al., 1990). Under Lithuanian climatic conditions, the rape rosette stage lasts up to 30-40 days, and the competitive ability of the crop during this period is very low (Velička, 2002). In our experiment, unfavourable meteorological conditions for rape growth and development occurred at the end of summer and the beginning of autumn in 2012; therefore, the rape crop was smothered by the weeds. In 2012, the density of winter rape in the SMT plot was 4.5-5.3 times lower than that in the TWC and MWC plots without the application of plant bio-activators and 3.5-3.7 times lower with the use of plant bio-activators. At the end of summer and in the autumn of 2013, meteorological conditions were more favourable for the growth and development of winter oilseed rape than in 2012, which resulted in a higher crop density. The density of the winter oilseed rape was 1.2-1.4 times lower in the SMT treatment compared with the TWC and MWC methods in the absence of plant bio-activators and 1.4-1.5 times lower in the presence of plant bio-activators. In SMT plots where winter oilseed rape was cultivated at an inter-row spacing of $12 \mathrm{~cm}$ compared with a wide row spacing of $48 \mathrm{~cm}$, in rows there was lower number of plants therefore the competition with weeds was higher. In 2013, there were no significant differences $(P \geq 0.05)$ between the winter oilseed rape crops densities in the plots where bio-activators were used compared with the plots where bio-activators were not used.

Prior to the weed control treatments in 2012, the number of weed seedlings in the winter oilseed rape cultivated in the soil with a regular humus layer ( $1^{\text {st }}$ experiment) in the SMT plot reached a peak (61.9$81.9 \mathrm{~m}^{-2}$ ), and this result was influenced by the low rape crop density. In SMT plots without the use of plant bioactivators, the number of weed seedlings was $1.2-2.0$ times higher compared with the TWC and MWC methods. The influence of plant bio-activators on weed seedling 
Table 1. Main weed species composition in the winter oilseed rape cultivated in the soil with a regular and thickened humus layers in autumn before and after the use of weed control methods, 2012-2013

\begin{tabular}{|c|c|c|c|c|c|c|c|}
\hline \multirow{3}{*}{ Weed species } & \multirow{3}{*}{$\begin{array}{l}\text { Application } \\
\text { of plant bio- } \\
\text { activators } \\
\text { (main plot } \\
\text { treatment) }\end{array}$} & \multicolumn{6}{|c|}{$\begin{array}{l}\text { Weed control method } \\
\text { (subplot treatment) }\end{array}$} \\
\hline & & \multicolumn{2}{|c|}{$\begin{array}{l}\text { thermal } \\
\text { (TWC) }\end{array}$} & \multicolumn{2}{|c|}{$\begin{array}{l}\text { mechanical } \\
\text { (MWC) }\end{array}$} & \multicolumn{2}{|c|}{$\begin{array}{l}\text { smothering } \\
\text { (SMT) }\end{array}$} \\
\hline & & before & after & before & after & before & after \\
\hline \multicolumn{8}{|c|}{ Regular humus layer ( $\left(1^{\text {st }}\right.$ experiment $)$} \\
\hline \multicolumn{8}{|c|}{2012} \\
\hline \multirow{2}{*}{ Stellaria media (L.) Vill. } & - & 17.5 & 14.4 & 14.4 & 6.9 & 11.9 & 10.0 \\
\hline & + & 11.9 & 8.8 & 11.3 & 11.9 & 11.9 & 13.7 \\
\hline \multirow{2}{*}{ Capsella bursa-pastoris (L.) Medik. } & - & 1.2 & 1.9 & 0 & 1.9 & 16.3 & 16.9 \\
\hline & + & 0.0 & 0.6 & 1.2 & 1.2 & 28.2 & 24.4 \\
\hline \multirow[b]{2}{*}{ Veronica arvensis $\mathrm{L}$. } & - & 0.0 & 0.0 & 5.6 & 1.2 & 1.9 & 14.4 \\
\hline & + & 0.0 & 0.0 & 8.8 & 5.0 & 6.2 & 28.8 \\
\hline Tripleurospermum perforatum (Mérat.) & - & 3.8 & 2.5 & 6.2 & 5.0 & 4.4 & 5.6 \\
\hline M. Laínz & + & 2.5 & 1.2 & 6.9 & 6.9 & 7.5 & 8.1 \\
\hline \multirow{2}{*}{ Lamium amplexicaule L. } & - & 0.6 & 2.5 & 8.1 & 8.1 & 11.2 & 15.6 \\
\hline & + & 1.2 & 0.6 & 10.0 & 11.2 & 12.5 & 15.0 \\
\hline \multirow{2}{*}{ Other } & - & 7.5 & 6.8 & 16.9 & 9.4 & 16.2 & 15.6 \\
\hline & + & 9.4 & 6.3 & 31.2 & 23.8 & 15.5 & 23.1 \\
\hline \multicolumn{8}{|c|}{2013} \\
\hline \multirow{2}{*}{ Veronica arvensis L. } & - & 58.1 & 53.8 & 42.5 & 6.2 & 28.8 & 41.2 \\
\hline & + & 46.2 & 26.9 & 40.6 & 10.0 & 29.4 & 58.8 \\
\hline \multirow{2}{*}{ Capsella bursa-pastoris (L.) Medik. } & - & 14.4 & 11.2 & 11.9 & 9.4 & 10.6 & 12.5 \\
\hline & + & 17.5 & 14.4 & 7.5 & 6.2 & 8.1 & 15.6 \\
\hline \multirow{2}{*}{ Lamium purpureum $\mathrm{L}$. } & - & 11.9 & 6.9 & 3.1 & 4.4 & 3.8 & 5.0 \\
\hline & + & 7.50 & 11.2 & 4.4 & 7.5 & 10.0 & 6.9 \\
\hline Stellaria media (L ) Vill. & - & 8.1 & 7.5 & 5.6 & 5.0 & 5.0 & 6.2 \\
\hline Stellaria meaia (L.) Vill. & + & 3.1 & 5.0 & 5.0 & 5.0 & 2.5 & 5.0 \\
\hline Tripleurospermum perforatum & - & 6.9 & 6.2 & 3.8 & 3.1 & 3.8 & 5.6 \\
\hline (Merat) M. Lainz & + & 3.1 & 4.4 & 1.2 & 0.0 & 2.5 & 3.1 \\
\hline & - & 14.4 & 10.6 & 10.0 & 6.3 & 9.4 & 8.1 \\
\hline Other & + & 13.2 & 10.6 & 1.9 & 2.4 & 8.1 & 10.0 \\
\hline & Thickened & mus laye & experi & & & & \\
\hline & & 2012 & & & & & \\
\hline Stellaria media (I ) Vill & - & 22.5 & 17.5 & 26.3 & 17.5 & 23.1 & 20.0 \\
\hline Stellarla media (L.) Vill. & + & 12.5 & 8.8 & 19.4 & 13.1 & 12.5 & 17.5 \\
\hline & - & 9.4 & 7.50 & 17.5 & 13.1 & 32.5 & 35.0 \\
\hline Sinapis arvensis L. & + & 12.5 & 8.1 & 28.8 & 20.6 & 16.3 & 10.6 \\
\hline & - & 0.0 & 3.1 & 0.0 & 1.9 & 33.1 & 25.0 \\
\hline Capsella bursa-pastoris (L.) Medik. & + & 0.0 & 1.9 & 0.0 & 2.5 & 31.9 & 30.0 \\
\hline Viela arupnsic Murra & - & 0.0 & 0.0 & 6.2 & 5.0 & 5.6 & 10.6 \\
\hline Viola arvensis Murray & + & 0.6 & 0.6 & 3.8 & 1.9 & 2.5 & 6.9 \\
\hline & - & 0.6 & 0.0 & 10.0 & 8.8 & 1.9 & 13.1 \\
\hline Veronica arvensis L. & + & 5.0 & 3.1 & 4.4 & 1.9 & 8.1 & 21.3 \\
\hline Other & - & 31.9 & 34.4 & 30.0 & 15.7 & 15.7 & 26.9 \\
\hline Other & + & 28.8 & 21.3 & 30.0 & 17.5 & 18.7 & 25.0 \\
\hline & & 2013 & & & & & \\
\hline & - & 16.3 & 10.0 & 8.8 & 13.1 & 19.4 & 25.0 \\
\hline Stellaria media (L.) Vill. & + & 11.9 & 8.8 & 13.1 & 15.6 & 18.8 & 20.0 \\
\hline & - & 10.0 & 6.9 & 6.2 & 1.2 & 10.0 & 13.8 \\
\hline Veronica arvensis L. & + & 5.0 & 5.6 & 10.0 & 3.8 & 12.5 & 18.8 \\
\hline Cansella hurcanastoric (I ) Medik & - & 8.1 & 8.8 & 12.5 & 6.2 & 8.8 & 9.4 \\
\hline Capsella bursa-pastorls (L.) Medik. & + & 5.6 & 6.2 & 10.0 & 6.2 & 8.1 & 6.2 \\
\hline & - & 6.2 & 10.0 & 3.1 & 1.9 & 4.4 & 3.1 \\
\hline Viola arvensis Murray & + & 6.2 & 6.2 & 1.9 & 3.8 & 1.2 & 2.5 \\
\hline & - & 5.0 & 3.8 & 0.6 & 0.6 & 3.8 & 3.1 \\
\hline Sinapis arvensis L. & + & 1.2 & 1.9 & 1.2 & 2.5 & 8.8 & 6.2 \\
\hline & - & 23.7 & 15.0 & 14.4 & 10.0 & 15.0 & 11.9 \\
\hline Other & + & 23.1 & 20.6 & 13.2 & 8.8 & 15.0 & 23.7 \\
\hline
\end{tabular}

- - plant bio-activators not applied, +- plant bio-activators applied 
Table 2. The influence of different weed control methods and plant bio-activators on the competitiveness of winter oilseed rape and weeds in the soil with regular and thickened humus layers, 2012-2013

\begin{tabular}{|c|c|c|c|c|c|c|}
\hline \multirow{3}{*}{$\begin{array}{l}\text { Weed control } \\
\text { method (subplot } \\
\text { treatment) }\end{array}$} & \multicolumn{6}{|c|}{ Plant bio-activators (main plot treatment) } \\
\hline & \multicolumn{3}{|c|}{ without application } & \multicolumn{3}{|c|}{ with application } \\
\hline & $\begin{array}{c}\text { oilseed rape } \\
\text { crop density, } \\
\text { plants } \\
\mathrm{m}^{-2} \\
\end{array}$ & $\begin{array}{c}\text { weed seedlings } \\
\mathrm{m}^{-2} \\
\text { (before weed } \\
\text { control) } \\
\end{array}$ & $\begin{array}{c}\text { weed seedlings } \\
\mathrm{m}^{-2} \\
\text { (after weed } \\
\text { control) } \\
\end{array}$ & $\begin{array}{c}\text { oilseed rape } \\
\text { crop density, } \\
\text { plants } \\
\mathrm{m}^{-2} \\
\end{array}$ & $\begin{array}{c}\text { weed seedlings } \\
\mathrm{m}^{-2} \\
\text { (before weed } \\
\text { control) } \\
\end{array}$ & $\begin{array}{c}\text { weed seedlings } \\
\mathrm{m}^{-2} \\
\text { (after weed } \\
\text { control) }\end{array}$ \\
\hline \multicolumn{7}{|c|}{ Regular humus layer ( $1^{\text {st }}$ experiment $)$} \\
\hline \multicolumn{7}{|c|}{2012} \\
\hline TWC & $57.3 \mathrm{a}^{*}$ & $30.6 \mathrm{~b}$ & $28.1 \mathrm{~b}$ & $30.5 \mathrm{a}^{*}$ & $25.0 \mathrm{~b}$ & $17.5 \mathrm{c}$ \\
\hline MWC & $48.5 \mathrm{a}$ & $51.3 \mathrm{a}$ & $32.5 b^{*}$ & $32.8 \mathrm{a}$ & $69.4 \mathrm{a}$ & $60.0 \mathrm{~b}^{*}$ \\
\hline SMT & $10.8 \mathrm{~b}$ & $61.9 \mathrm{a}$ & $78.1 \mathrm{a}$ & $8.75 \mathrm{~b}$ & $81.9 \mathrm{a}$ & $113.1 \mathrm{a}$ \\
\hline \multicolumn{7}{|c|}{2013} \\
\hline TWC & $79.9 \mathrm{~b}$ & $113.8 \mathrm{a}^{*}$ & $96.2 \mathrm{a}^{*}$ & $87.1 \mathrm{a}$ & $90.6 \mathrm{a}^{*}$ & $72.5 b^{*}$ \\
\hline MWC & $97.0 \mathrm{a}$ & $76.9 \mathrm{~b}^{*}$ & $34.4 \mathrm{~b}$ & $85.8 \mathrm{a}$ & $60.6 b^{*}$ & $31.2 \mathrm{c}$ \\
\hline SMT & $67.0 \mathrm{~b}$ & $61.3 \mathrm{c}$ & $78.7 \mathrm{a}$ & $59.0 \mathrm{~b}$ & $60.6 \mathrm{~b}$ & $99.4 \mathrm{a}$ \\
\hline \multicolumn{7}{|c|}{ Thickened humus layer ( $2^{\text {nd }}$ experiment $)$} \\
\hline \multicolumn{7}{|c|}{2012} \\
\hline TWC & $61.8 \mathrm{a}^{*}$ & $64.4 \mathrm{~b}$ & $62.5 \mathrm{~b}$ & $35.3 \mathrm{a}^{*}$ & $59.4 \mathrm{a}$ & $43.8 \mathrm{~b}$ \\
\hline MWC & $49.3 \mathrm{a}^{*}$ & $90.0 \mathrm{ab}$ & $61.9 \mathrm{~b}$ & $27.5 \mathrm{a}^{*}$ & $86.3 \mathrm{a}$ & $57.5 \mathrm{~b}$ \\
\hline SMT & $10.5 \mathrm{~b}$ & $111.9 \mathrm{a}$ & $130.6 \mathrm{a}$ & $11.2 \mathrm{~b}$ & $90.0 \mathrm{a}$ & $111.3 \mathrm{a}$ \\
\hline \multicolumn{7}{|c|}{2013} \\
\hline TWC & $79.6 \mathrm{a}$ & $69.4 \mathrm{a}$ & $54.4 \mathrm{a}$ & $90.5 \mathrm{a}$ & $53.1 \mathrm{a}$ & $49.4 \mathrm{~b}$ \\
\hline MWC & $77.2 \mathrm{a}$ & $45.6 \mathrm{a}$ & $33.1 \mathrm{~b}$ & $81.4 \mathrm{a}$ & $49.4 \mathrm{a}$ & $40.6 \mathrm{~b}$ \\
\hline SMT & $52.2 \mathrm{~b}$ & $61.3 \mathrm{a}$ & $66.3 \mathrm{a}$ & $51.5 \mathrm{~b}$ & $64.4 \mathrm{a}$ & $77.5 \mathrm{a}$ \\
\hline
\end{tabular}

Note. Means not sharing a common letter (a, b, c) (subplot treatment) and with asterisk $(*)$ (main plot treatment) are significantly different $(P<0.05)$; TWC - thermal weed control, MWC - mechanical weed control, SMT - smothering.

number was not significant $(P \geq 0.05)$. In 2013, the number of weed seedlings was, on average, $44.8 \%$ higher than in 2012, but the dense winter oilseed rape crop had greater competitive ability. More favourable conditions for the spread of the weeds occurred in the MWC and TWC plots, because of wide inter-row spacing $(48 \mathrm{~cm})$. The number of weed seedlings in these plots ranged between 60.6 and $113.8 \mathrm{~m}^{-2}$. In the TWC and MWC plots, sufficient humidity and more favourable light conditions without the use of plant bio-activators resulted in a significantly $(P \leq 0.05)$ higher number $(1.3-1.9$ times $)$ of germinated weed seedlings compared with the SMT plots. The use of plant bio-activators had positive effect on the growth and development of winter oilseed rape and in the TWC and MWC plots significantly $(P \leq 0.05)$ reduced the number of weed seedlings (from $20.4 \%$ to $21.2 \%$ ).

In 2012, after TWC and MWC were applied, the number of weed seedlings was significantly $(P \leq$ $0.05)$ lower (2.4-2.8 times) without the use of plant bioactivators and was 1.9 to 6.5 times lower with their use compared with the SMT treatment. The number of weed seedlings did not differ significantly $(P \geq 0.05)$ between the TWC and MWC methods without the application of plant bio-activators. TWC using water steam and plant bio-activators significantly $(P \leq 0.05)$ reduced the number of weed seedlings by 3.5 times compared with the MWC. The TWC method was the most efficient for annual dicotyledonous weeds. The most abundant weed species in winter oilseed rape, S. media, decreased by $26.5 \%$ (Table 1). Virbickaite et al. (2006) suggested that with the use of water steam for weed control, the spread of $S$. media can be reduced by up to $100 \%$.
Other authors indicated that TWC is most effective for the weeds forming apical bud in apex (Chenopodium album, S. media, etc.). Control of monocotyledons of Poa family and dicotyledons forming rosette (Capsella bursa-pastoris, etc.) using this weed control method is not sufficient (Sirvydas, Kerpauskas, 2012).

After weed control application in the MWC and SMT treatments in 2013, in the soil with a regular humus layer ( $1^{\text {st }}$ experiment) the number of weeds was 1.5-1.8 times higher with the use of plant bio-activators compared with their non-use, and this was impacted by a lower crop density. A significantly $(P \leq 0.05)$ lower number of weeds was found after the application of MWC compared with TWC and SMT. In all treatments, the weed number was significantly $(P \leq 0.05)$ lower $(2.3$ to 2.8 times) without the use of plant bio-activators and was 2.3 to 3.2 times lower when plant bio-activators were used. It shows that winter oilseed rape smothering ability of weeds can be increased with the use of plant bio-activators. The application of MWC in the winter oilseed rape crop decreased the most abundant weed (Veronica arvensis) by $85.3 \%$ without the use of plant bio-activators and by $75.4 \%$ with the use of bio-activators (Table 1). There were no significant differences $(P \geq$ 0.05 ) between the TWC plots without plant bio-activators and the SMT plots with respect to the number of weed seedlings (Table 2). Using plant bio-activators and TWC, the number of weed seedlings was significantly $(P \leq 0.05)$ decreased by $27.1 \%$ compared with the SMT treatment. The use of plant bio-activators significantly $(P \leq 0.05)$ reduced the number of weed seedlings by $24.6 \%$ only when the TWC method was used. 
In both experimental years (2012 and 2013), in the soil with a thickened humus layer ( $2^{\text {nd }}$ experiment) the lowest crop density occurred in SMT treatment (Table 2). In this treatment in 2012, the number of winter oilseed rape plants per unit area was significantly $(P \leq 0.05)$ lower (4.7-5.9 times) without the use of plant bio-activators and 2.5-3.2 times lower with the use of bio-activators compared with the TWC and MWC methods. In 2013, the winter oilseed rape crop density in the SMT plots was significantly $(P \leq 0.05)$ lower $(1.5$ times $)$ without the use of plant bio-activators and 1.6-1.8 times lower with the use of bio-activators compared with the TWC and MWC methods. In 2012, the rape crop density was lower in the all the plots where plant bio-activators were used.

In both years of the experiment, in the soil with a thickened humus layer the highest number of weed seedlings was found in the SMT plots. However, compared with the TWC and MWC plots, the differences were not significant $(P \geq 0.05)$.

After weed control application in 2012 in the soil with a thickened humus layer ( $2^{\text {nd }}$ experiment), the highest number of weed seedlings was measured in the SMT plots compared with the TWC and MWC plots. The number of weed seedlings in the TWC and MWC plots was significantly $(P \leq 0.05)$ lower $(2.1$ times $)$ than that in the SMT plots when plant bio-activators were not applied; the use of plant bio-activators reduced the number of weed seedlings 1.9-2.5 times. The number of weed seedlings in TWC and MWC treatments did not differ significantly $(P \geq 0.05)$. In 2013 , the number of weed seedlings without the use of plant bio-activators was significantly $(P \leq 0.05)$ lower $(1.6$ to 2.0 times $)$ only in the plots where MWC was used compared with the TWC and SMT treatments. The application of MWC in soil with thickened humus layer decreased the number of Veronica arvensis by $62.5-80.0 \%$ and lowered the number of $C$. bursa-pastoris by $37.5-50.0 \%$ (Table 1 ). Both the TWC and MWC methods significantly $(P \leq$ 0.05 ) reduced the number of weed seedlings (1.6 to 1.9 times) in the presence of plant bio-activators compared with the SMT treatment (Table 2). The use of plant bioactivators had no significant $(P \geq 0.05)$ effect on the number of weed seedlings in 2013 in all weed control treatments. The efficiency of plant bio-activators to a large extent depends on the meteorological conditions during crop vegetation.

The efficiency of different weed control methods and plant bio-activators in the autumn vegetation period. The assessment of the efficiency of different weed control methods in the soil with a regular humus layer ( $1^{\text {st }}$ experiment) revealed that without the use of plant bio-activators, the MWC efficiency was 3.6 to 4.5 times higher than that of TWC in 2012 and 2013 (Fig. $2 \mathrm{~A}$ ). In the presence of plant bio-activators (only in 2013), the efficiency of MWC was 2.4 times higher than that of TWC. In 2012, the TWC efficiency was 2.2 times
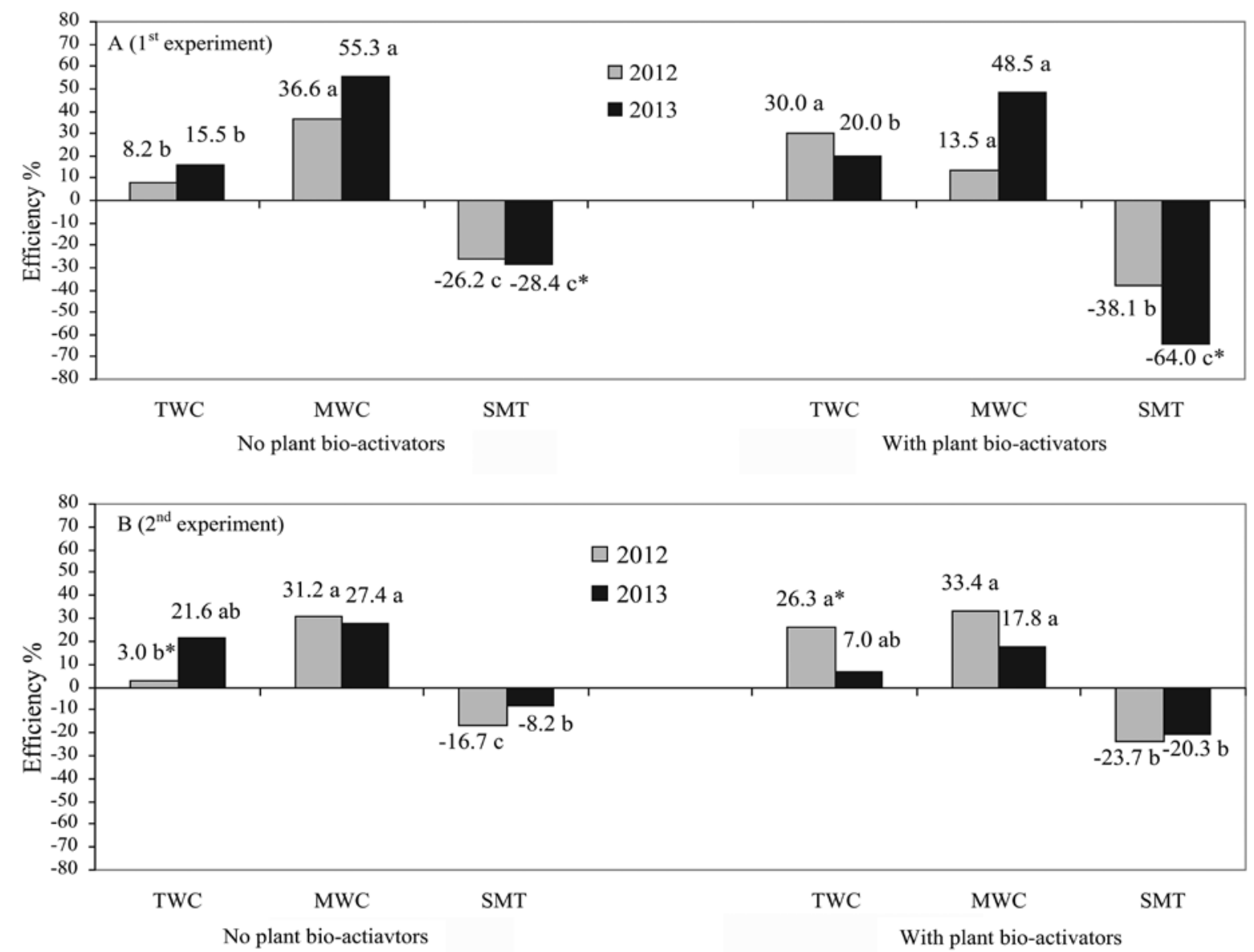

Note. Means not sharing a common letter (a, b, c) (subplot treatment) and with asterisk $(*)$ (main plot treatment) are significantly different $(P<0.05)$; TWC - thermal weed control, MWC - mechanical weed control, SMT - smothering.

Figure 2. The efficiency of different weed control methods and plant bio-activators in the autumn vegetation period in the soil with a regular (A) and thickened (B) humus layer, 2012-2013 
higher than that of MWC. In both experimental years, the efficiency of weed control in SMT was negative; seven days after the weed control treatment, the number of weeds increased from $26.2 \%$ to $64.0 \%$ of the initial density. The use of plant bio-activators, compared with their non-use, reduced weed control efficiency in the SMT treatment from 1.5 to 2.2 times. Veronica arvensis was the most abundant weed in the SMT plots (Table 1).

In 2012, in the soil with a thickened humus layer ( $2^{\text {nd }}$ experiment), the MWC method without the use of plant bio-activators was 10.4 times more efficient than the TWC method (Fig. 2 B). In 2013, the efficiency of the MWC and TWC methods was similar. Using plant bio-activators in 2012, the efficiencies of these methods did not differ significantly $(P \geq 0.05)$; however, in 2013, the MWC method was 2.6 times more efficient than the TWC method. The use of plant bio-activators enhanced the efficiency of TWC 8.8 times (only in 2012). The SMT treatment was not effective for weed control. Seven days after weed control application in the TWC and MWC plots, the number of weeds decreased by $3.0-33.4 \%$ compared with an increase of $8.2-23.7 \%$ in the SMT plots. The use of plant bio-activators in SMT plots, compared with their non-use, reduced weed control efficiency up to 1.4-2.5 times in the soil with a thickened humus layer.

\section{Conclusions}

1. The crop density of winter oilseed rape in the smothering (SMT) plots (with or without the use of plant bio-activators) was 1.2-5.3 times lower compared with the mechanical (MWC) and thermal (TWC) weed control methods in the soil with a regular humus layer and 1.5-5.9 times lower in the soil with a thickened humus layer. The crop density under unfavourable (dry) meteorological conditions in the presence of the plant bio-activators was not improved compared with that in the treatments without plant bio-activators.

2. In winter oilseed rape during autumn vegetation period, 20-22 weed species were found, including 18-19 annuals. Stellaria media (L.) Vill., Veronica arvensis L., Sinapis arvensis L., Capsella bursa-pastoris (L.) Medik. were dominating weeds. The most abundant weed (Veronica arvensis L.) in the winter oilseed rape crop was reduced by $75.4-85.3 \%$ with the use of MWC compared with the SMT treatment. The TWC method effectively reduced the spread of annual dicotyledonous weeds.

3 . In the soil with a regular humus layer, the number of weed seedlings in the plots where MWC was applied was significantly $(P \leq 0.05)$ lower $(2.3-2.4$ times) and 1.9-3.2 times lower with the use of plant bioactivators compared with the plots where SMT was used (without the use of plant bio-activators). In the soil with a thickened humus layer, TWC and MWC significantly $(P \leq$ 0.05 ) reduced the number of weed seedlings between 1.2 and 2.1 times compared with SMT in the absence of plant bio-activators. In the presence of plant bio-activators, the number of weed seedlings was reduced between 1.6 and 2.5 times. Weeds were controlled more effectively in the soil with a thickened humus layer compared with the soil with a regular humus layer.

4. In both soil types, with a regular and a thickened humus layer, the weed control of the SMT treatment was not effective. MWC was more effective than TWC. The efficiency of TWC was enhanced in the presence of plant bio-activators in winter oilseed rape grown in a regular humus layer; in a thickened humus layer the efficiency depended on the meteorological conditions. It is recommended in organic winter oilseed rape cultivation to use a wide row spacing of $48 \mathrm{~cm}$ for MWC application.

Received 23092015

Accepted 11012016

\section{References}

Arlauskienė A., Maikštènienė S. 2004. The effect of preceding crops and organic fertilizers on the occurrence of shortlived weeds in different agrosystems. ZemdirbysteAgriculture, 88 (4): 102-116

Ascard J. 1998. Comparison of flawing and infrared radiation techniques for thermal weed control. Weed Research, 38 (1): $69-76$ http://dx.doi.org/10.1046/j.1365-3180.1998.00073.x

Bečka D., Vašák J., Kroutil P., Štranc P. 2004. Autumn growth and development of different winter oilseed rape variety types at three input levels. Plant, Soil and Environment, 50 (4): 168-174

Bullied W. J., Van Acker R. C., Marginet A. M., Kenkel N. C. 2006. Agronomic and environmental factors influence weed composition and canola competitiveness in southern Manitoba. Canadian Journal of Plant Science, 86 (2): 591-599

http://dx.doi.org/10.4141/P05-042

Chamanabad H. M. D., Asghari A. 2009. The effect of crop rotation, mineral fertilizer application and herbicide on weed control in winter rye. Journal of Science and Technology of Agriculture and Natural Resources, 13 (47): 601-610

Datta A., Knezevic S. Z. 2013. Flaming as an alternative weed control method for conventional and organic agronomic crop production systems: a review. Advances in Agronomy, 118: $399-428$ http://dx.doi.org/10.1016/B978-0-12-405942-9.00006-2

Engström L., Stenberg M., Wallenhammar A.-Ch., Ståhl P., Gruvaeus I. 2014. Organic winter oilseed rape response to $\mathrm{N}$ fertilisation and preceding agroecosystem. Field Crops Research, 167: 94-101 http://dx.doi.org/10.1016/j.fcr.2014.07.011

Hansson D., Ascard J. 2002. Influence of developmental stage and time of assessment on hot water weed control. Weed Research, 42: 307-317 http://dx.doi.org/10.1046/j.1365-3180.2002.00290.x 
IUSS Working Group WRB. 2014. World reference base for soil resources 2014. International soil classification system for naming soils and creating legends for soil maps. World soil resources reports No. 106. FAO, Rome

Jablonskytė-Raščè D., Maikštėnienè S., Cesevičienė J., Mankevičienė A. 2012. Effect of ecologic fertilizers and bio-activators on productivity and yield quality of common (Triticum aestivum L.) and spelt (Triticum spelta L.) wheat. Žemès ūkio mokslai, 19 (1): 1-10 (in Lithuanian)

Kempenaar C., Spijker J. H. 2004. Weed control on hard surfaces in the Netherlands. Pest Management Science, 60: $595-599$ http://dx.doi.org/10.1002/ps.863

Kerpauskas P., Sirvydas P. A., Lazauskas P., Vasinauskienė R., Tamošiūnas A. 2006. Possibilities of weed control by water steam. Agronomy Research, 4: 221-225

Maikštėnienè S., Arlauskienė A., Velykis A., Satkus A. 2009. Enchancement of competitive ability of cereals towards weeds by means of crop rotations. ZemdirbysteAgriculture, 96 (2): 23-34

Mohammaddoust-e-Chamanabad H. R., Baghestani M. A., Tulikov A. M. 2006. The impact of agronomic practices on weed community in winter rye. Pakistan Journal of Weed Science Research, 12 (4): 281-291

Morrison M. J., Mcvetty P. B. E., Scarth R. 1990. Effect of altering plant density on growth characteristics of summer rape. Canadian Journal of Plant Science, 70: 139-149 http://dx.doi.org/10.4141/cjps90-016

Pekarskas J., Raškauskienė A., Gavenauskas A. 2013. The influence of liquid bioorganic fertilizers and growth activators on organic Poaceae cereal biometric parameters and segetic flora. Proceedings of the $19^{\text {th }}$ international scientific-practical conference Human and Nature Safety 2013. Aleksandras Stulginkis University, p. 60-63

Pupalienè R. 2004. The residual effect of different agricultural systems on spring barley agrocoenosis: summary of doctoral dissertation. Lithuanian University of Agriculture, $126 \mathrm{p}$.

Quarles W. 2004. Thermal weed management: hot alternatives for urban areas and organic farms. IPM Practitioner, 26: $1-9$

Sirvydas P. A., Kerpauskas P. 2012. Thermal weed control: monograph. Aleksandras Stulginskis University, 327 p. (in Lithuanian)

Sliesaravičius A., Pekarskas J., Rutkovienė V., Baranauskis K. 2006. Grain yield and disease resistance of winter cereal varieties and application of biological agent in organic agriculture. Agronomy Research, 4: 371-378

Staniulienè R. 2010. The impact of high-temperature environment on weeds highly resistant to thermal killing: summary of the doctoral dissertation. Lithuanian University of Agriculture, $80 \mathrm{p}$.

Tarakanovas P. 2002. Data transformation of biological experiments using a computer program ANOVA. Zemdirbyste-Agriculture, 77: 170-180 (in Lithuanian)

Ulloa S. M., Datta A., Bruening C., Gogos G., Arkebauer T. J., Knezevic S. Z. 2012. Weed control and crop tolerance to propane flaming as influenced by the time of day. Crop Protection, 31: 1-7 http://dx.doi.org/10.1016/j.cropro.2011.09.005
Valantin-Morison M., Meynard J.-M., Dore T. 2007. Effects of crop management and surrounding field environment on insect incidence in organic winter oilseed rape (Brassica napus L.). Crop Protection, 26 (8): 1108-1120 http://dx.doi.org/10.1016/j.cropro.2006.10.005

Velička R. 2002. Oilseed rape: monograph. Lithuanian University of Agriculture, 320 p. (in Lithuanian)

Veromann E., Saarniit M., Kevväi R., Luik A. 2009. Effect of crop management on the incidence of Meligethes aeneus Fab. and their larval parasitism rate in organic and conventional winter oilseed rape. Agronomy Research, 7 (spec. iss. I): 548-554

Virbickaite R., Sirvydas P. A., Kerpauskas P., Vasinauskienė R. 2006. The comparison of thermal and mechanical systems of weed control. Agronomy Research, 4: 451-455 
ISSN 1392-3196 / e-ISSN 2335-8947

Zemdirbyste-Agriculture, vol. 103, No. 1 (2016), p. 11-20

DOI 10.13080/z-a.2016.103.002

\title{
Žieminių rapsų ir piktžolių konkurencija ekologinėje žemdirbystẻje taikant nechemines piktžolių kontrolès priemones
}

\author{
R. Velička ${ }^{1,2}$, A. Marcinkevičienè $\dot{1}^{1,2}$, R. Pupalienè $\dot{1}^{1,2}$, L. M. Butkevičienè $\dot{1}^{1,2}$, R. Kosteckas², \\ S. Čekanauskas ${ }^{2}$, Z. Kriaučiūniené ${ }^{2}$
}

${ }^{1}$ Aleksandro Stulginskio universiteto Agroekosistemų ir dirvožemio mokslų institutas

${ }^{2}$ Aleksandro Stulginskio universiteto Bandymų stotis

\section{Santrauka}

Viena iš priežasčių, kodèl ekologiniuose ūkiuose nedidèja rapsų plotai, yra piktžolių, ligų bei kenkèjų kontrolès problema ir mažas sẻklų derlingumas. Trūksta mokslinių tyrimų apie rapsų auginimą ekologinės žemdirbystės sistemoje, ypač taikant šiuolaikines inovatyvias piktžolių kontrolès priemones. Todèl 2012-2013 m. Aleksandro Stulginskio universiteto Bandymų stotyje buvo atlikti tyrimai, kurių tikslas - nustatyti ir ịvertinti įvairių necheminių piktžolių kontrolès būdų (terminio, mechaninio bei stelbimo) ịtaką žieminių rapsų ir piktžolių konkurencingumui rudens vegetacijos laikotarpiu ekologinèje žemdirbystèje naudojant biologinius preparatus ir jų nenaudojant. Žieminiai rapsai auginti dirvožemyje su nepastorintu $(23-25 \mathrm{~cm})(1$ eksperimentas $)$ ir pastorintu $(48-50 \mathrm{~cm})$ (2 eksperimentas) armens sluoksniais. Atlikus tyrimus nustatyta, kad taikant stelbimą ir naudojant biologinius preparatus bei jų nenaudojant žieminių rapsų tankumas, lyginant su kitais piktžolių kontrolès būdais, buvo esmingai $(P \leq 0.05)$ mažesnis nuo 1,2 iki 5,3 karto dirvožemyje su nepastorintu armens sluoksniu ir nuo 1,5 iki 5,9 karto dirvožemyje su pastorintu armens sluoksniu. Žieminių rapsų pasėlyje rudens vegetacijos laikotarpiu buvo rastos 20-22 piktžolių rūšys, iš jų 18-19 - trumpaamžių. Labiausiai paplitusios buvo Stellaria media (L.) Vill., Veronica arvensis L., Sinapis arvensis L. ir Capsella bursa-pastoris (L.) Medik. Dirvožemyje su nepastorintu ir pastorintu armens sluoksniu terminè bei mechaninè piktžolių kontrolè, lyginant su stelbimu, esmingai $(P \leq$ $0,05)$ nuo 1,1 iki 1,9 karto sumažino piktžolių daigų kiekį, kai biologiniai preparatai buvo naudojami. Stelbimo efektyvumas piktžolėms buvo neigiamas dirvožemyje ir su nepastorintu, ir su pastorintu armens sluoksniais. Piktžolių mechaninis naikinimas buvo efektyvesnis nei terminis. Terminio piktžolių naikinimo efektyvumą didino biologinių preparatų naudojimas.

Reikšminiai žodžiai: biologiniai preparatai, Brassica napus, mechaninė piktžolių kontrolè, pasèlio stelbiamoji geba, piktžolių rūšys, terminè piktžolių kontrolè.

Please use the following format when citing the article:

Velička R., Marcinkevičienė A., Pupalienė R., Butkevičienė L. M., Kosteckas R., Čekanauskas S., Kriaučiūnienė Z. 2016. Winter oilseed rape and weed competition in an organic farming using non-chemical weed control. Zemdirbyste-Agriculture, 103 (1): 11-20 DOI 10.13080/z-a.2016.103.002 